\title{
Short Communication: Two new species and new record of Psydrax Gaertn. (Rubiaceae: Vanguerieae) in Borneo
}

\author{
RIDHA MAHYUNI ${ }^{1,2, \vartheta}$, TATIK CHIKMAWATI ${ }^{3}$, NUNIK SRI ARIYANTI ${ }^{3}$ \\ ${ }^{1}$ Plant Biology Graduate Program, Department of Biology, Faculty of Mathematics and Natural Sciences, Institut Pertanian Bogor. Jl. Raya Dramaga, \\ Kampus IPB Dramaga, Bogor 16680, West Java, Indonesia \\ ${ }^{2}$ Herbarium Bogoriense, Botany Division, Research Center for Biology, Indonesian Institute of Sciences. Cibinong Science Center, Jl. Raya Jakarta- \\ Bogor Km. 46, Cibinong, Bogor 16911, West Java, Indonesia. Tel.: +62-21-87907604; 87907636, Fax.: +62-21-87907612 "email: \\ ridhamahyuni@gmail.com \\ ${ }^{3}$ Department of Biology, Faculty of Mathematics and Natural Sciences, Institut Pertanian Bogor. Jl. Raya Dramaga, Kampus IPB Dramaga, Bogor 16680, \\ West Java, Indonesia
}

Manuscript received: 29 January 2019. Revision accepted: 29 June 2019.

\begin{abstract}
Mahyuni R, Chikmawati T, Ariyanti NS. 2019. Short Communication: Two new species and new record of Psydrax Gaertn. (Rubiaceae: Vanguerieae) in Borneo. Biodiversitas 20: 2011-2015. Psydrax sabahensis Mahyuni and P. wongii Mahyuni are two new species endemic to Borneo proposed in this present study with descriptions, illustrations and map of distribution provided. Psydrax sabahensis has blades ovate to elliptic, with angle $60^{\circ}$ to the midrib, tertiary venation conspicuous on both side, petiole length 10-13 mm long, inflorescence sub-umbellate and pedicels 23-27 mm long. Psydrax wongii has blade elliptic, with angle $45^{\circ}$ to midrib, apex acuminate to caudate, secondary veins 3-4 pairs, tertiary venation inconspicuous on upper side and slightly wrinkled on lower surface. The presence of $P$. maingayi (Hook.f.) Bridson in Borneo, previously thought to be a Malay Peninsula endemic species, is also confirmed as a new record.
\end{abstract}

Keywords: Brunei Darussalam, Kalimantan, plant, Sabah, Sarawak

\section{INTRODUCTION}

The first modern survey of Psydrax (Rubiaceae) in Borneo appears to be the checklist of seven species identified only by numbers ("sp 1 to 7") in Coode et al. (1996). Mahyuni et al. (2018) continued the study and published a new combination, $P$. sumatranus Wong \& Mahyuni (2018) based on Canthium sumatranum Miq. Moreover also proposed two new combinations, $P$. approximatus (Korth.) Mahyuni \& K.M. Wong and $P$. lucidulus (Miq.) Mahyuni \& K.M. Wong, based on $C$. approximatum Korth and Vangueria lucidula Miq., respectively, both also occurring in Borneo.

This study is part of an on-going project revising the genus Psydrax in Borneo. Two new species are proposed here, namely $P$. sabahensis Mahyuni and $P$. wongii Mahyuni with description and illustrations provided. Their known distribution covers Sabah and Sarawak (Malaysia), and Brunei Darussalam. Psydrax maingayi was previously known only from the Malay Peninsula (Bridson, 1985; Wong 1989), but is here recorded for Borneo, i.e. East Kalimantan, Brunei Darussalam, and Sabah.

\section{MATERIALS AND METHODS}

Morphological observations and description included both, vegetative characteristics as well as flowers and fruits, using herbarium specimens. The collections of the
Bogoriense (BO), Forest Research Institute of Malaysia (KEP), Sarawak Forest Department (SAR) and Singapore Botanic Gardens (SING) herbaria were consulted. The descriptions and all measurements provided are from herbarium specimens.

\section{RESULTS AND DISCUSSION}

The numbers of species of Psydrax have been reported by Coode et al. (1996), three of them are new combination. Meanwhile, the other species are not yet known. Both of these taxa were compared with four species from Borneo; $P$. sumatranus, $P$. maingayi, $P$. lucidulus and $P$. approximatus and founded some characters distinguished of them. A comparison morphological characteristics of these species is provided with fourteen characters chosen in Table 1.

From Table 1. It can appear that these taxa can be distinguished by the value characters like texture of blades, apex shape, tertiary venation on both of leaf surface, peduncle length, inflorescence form, length of corolla tube and corolla lobe. Psydrax wongii has unique character of tertiary venation on abaxial leaf surface (wrinkled) and it can not find to the other species. For P. sabahensis and $P$. maingayi can hardly be distinguished by hairiness on blade, tertiary venation on abaxial and adaxial leaf surface, length of peduncle and number of flower per inflorescence. 
Table 1. Morphological comparison of Psydrax approximatus, P. lucidulus, P. sumatranus, $P$. sabahensis, $P$. wongii and P. maingayi

\begin{tabular}{|c|c|c|c|c|c|c|}
\hline Characters & $\begin{array}{c}\text { Psydrax } \\
\text { sumatranus }\end{array}$ & Psydrax lucidulus & $\begin{array}{c}\text { Psydrax } \\
\text { approximatus }\end{array}$ & Psydrax sabahensis & Psydrax wongii & $\begin{array}{l}\text { Psydrax } \\
\text { maingayi }\end{array}$ \\
\hline \multicolumn{7}{|l|}{ Leaf } \\
\hline Petiole length (mm) & $(3-) 6-10$ & $3-6(-10)$ & $4-7(-13)$ & $10-13$ & $6-9$ & $10-15$ \\
\hline Size of blade $(\mathrm{cm})$ & $5-15 \times 2.3-6.2(-7.5)$ & $3.4-8(-10.5) \times 1.2-2.6(-4.7)$ & $5-8.5(-10) \times 3.5-5.5$ & $(2.7-) 8-16 \times(4.3-) 6-7.7$ & $(2-) 4-10(-11.5) \times(-1) 1.5-3.5$ & $(8-) 14-20 \times(3-) 4-) 11$ \\
\hline Hairiness on blades & glabrous & glabrous & glabrous & glabrous & glabrous & velvety hairy \\
\hline Leaf texture & coriaceous & chartaceous & subcoriaceous & coriaceous & coriaceous & coriaceous \\
\hline Apex & acute to acuminate & apiculate with blunt tip & apiculate & acute to short cuspidate & acuminate to caudate & acuminate \\
\hline Tertiary venation on adaxial leaf surface & inconspicuous & inconspicuous & inconspicuous & conspicuous & inconspicuous & inconspicuous \\
\hline Tertiary venation on abaxial leaf surface & inconspicuous & inconspicuous & inconspicuous & conspicuous & slightly raised (wrinkled) & slightly raised \\
\hline Surface on adaxial leaf surface & shagreen & smooth & smooth & smooth & smooth & shagreen \\
\hline Petiole length $(\mathrm{mm})$ & $(3-) 6-10$ & $3-6(-10)$ & $4-7(-13)$ & $10-13$ & $6-9$ & $10-15$ \\
\hline \multicolumn{7}{|l|}{ Inflorescence } \\
\hline Peduncle length (mm) & $0-3$ & $2-4(-5)$ & $2-2.5$ & c. 2 & c. 3 & $10-13$ \\
\hline Inflorescence form & cyme & cyme & cyme & sub-umbellate & sub-umbellate & cyme \\
\hline Number of flowers per inflorescence & $20-30$ & $7-22$ & $20-40$ & $\leq 20$ & $15-20$ & $50-60$ \\
\hline Corolla tube length (mm) & c. 3 & c. 1 & $2-2.5(3)$ & $2-3$ & c. 3 & $2.5-3$ \\
\hline Corolla lobe length (mm) & c. 2.5 & c. 1.5 & $1.5-2.5$ & $3-4$ & c. 3 & $2.5-3$ \\
\hline
\end{tabular}




\section{Taxonomy}

Psydrax sabahensis Mahyuni, spec. nov. (Figure 1)

Diagnosis: Psydrax sabahensis is similar to $P$. maingayi due blade ovate to elliptic and coriaceous. It differs from $P$. maingayi the glabrous leaves, subumbellate inflorescence, length of peduncle (c. $2 \mathrm{~mm}$ long), and numbers of flowers about 20 per inflorescences. Psydrax maingayi has velvety hairs on leaf, cyme inflorescences, length of peduncle more than $10 \mathrm{~mm}$ long, number of flowers 50-60 in inflorescences.

Type: Borneo, Sabah, Lahad datu, Mt. Silam, 11 August 1984, Aban et al. 67520 (holo: KEP; iso: SAN) (Figure 1).

Description: Small to medium tree to $15 \mathrm{~m}$ tall, bark smooth and fissured. Stipules ovate 2-2.5 mm long and keeled apical acuminate 1-2 mm long. Leaves: blades ovate to elliptic, (2.7-)8-16 × (4.3-)6-7.7 cm, apex acute to short cuspidate, base cuneate, margin plane, secondary veins 5-6 pairs, midrib flat on both side, secondary vein flat on upper surfaces, slightly raised on lower surfaces, tertiary veins slightly conspicuous on upper surface, with angle $60^{\circ}$ to the midrib coriaceous, both surfaces smooth, glabrous; petioles 10-13 mm long. Inflorescences with peduncle sessile to subsessile (c. $2 \mathrm{~mm}$ long), sparsely scabrid, congest, sub-umbellate, number of flowers 20 per inflorescence. Flowers with pedicel 9-10 mm long, densely scabrid, calyx and hypanthium 2-3 mm long, including 5 triangular lobes, sparsely hairy all over; corolla tube $2-3 \mathrm{~mm}$ long, lobes 3-4 $\mathrm{mm}$ long; inner surface densely minute-hairy, throat with dense erect hairs; filaments $c$. $1 \mathrm{~mm}$ long, anthers 1-1.5 $\mathrm{mm}$ long, the whole reflexed and exerted; style $9-10 \mathrm{~mm}$ long, stigma 0.8-1 mm long. Fruits broadly ellipsoid, bilobed, 3-6 × 4-9 mm; pedicels 23-27 mm long. Pyrene ellipsoid, slightly rugose.

Additional specimens examined: Malaysia: Sarawak: Pelagus, Kapit, 14 July 1979, Bernard S. 40674 (SAR). Sabah: Tongod, 3 January 2004, J.B. Sugau et al. SAN 142193 (KEP, SAN); Sandakan, 23 July 1972, Leopold \& Amin SAN 75359 (SAN).

Etymology: The epithet of sabahensis is named in reference to the type locality of this species.

Distribution: Endemic to Borneo (Sabah and Sarawak). (Figure 2) to July.

Phenology: Flowering in August. Fruiting from January

Conservation status: There is no information about this species in the field. Its distribution in Sabah, Sarawak (only from 4 location) suggests that it is rare. Given the widespread landscape changes in these parts of Borneo. Based on the categories of the IUCN (2001) that species is EN A1c.

\section{Psydrax wongii Mahyuni, spec, nov. (Figure 3).}

Diagnosis: Psydrax wongii is similar to P. lucidulus due blades elliptic, inconspicuous tertiary veins on upper side and glossy. However, it differ from $P$. wongii by the coriaceous leaves, 3-4 secondary veins, wrinkled on lower of leaf surface and sub-umbellate in inflorescence. Psydrax lucidulus has chartaceous leaves, 5-6 secondary tertiary, flat on lower leaf surface and congested, cyme inflorescence.
Type: Borneo. Sarawak, Kuching, 4 October 1957, E.F. Brunig S 9523 (holo: SING; iso: SAR)

Description: Shrub to small tree to $10 \mathrm{~m}$ tall; bark smooth to slightly fissured. Stipules with a broad triangular base, 2-8 $\mathrm{mm}$ long and keeled apical cuspidate, 1-2 mm long. Leaves: blades elliptic, (2-)4-10 (-11.5) $\times(-1) 1.5-3.5$ $\mathrm{cm}$, apex acuminate to caudate, base cuneate, margin plane, secondary veins 3-4 pairs, flat on both sides, tertiary veins inconspicuous on upper side, slightly wrinkled on lower surface, entire of midrib, with angle to midrib $45^{\circ}$, glossy on upper surface; coriaceous, glabrous; petioles 6-9 $\mathrm{mm}$ long. Inflorescences with peduncle sessile to sub sessile ( $c$. $3 \mathrm{~mm}$ long), congest, sub-umbellate sparsely scabrid, number of flowers 15-20 per inflorescence. Flowers with pedicel densely scabrid, 2-5 $\mathrm{mm}$ long, calyx and hypanthium 1-1.5 mm long, including 5 triangular lobes, sparsely hairy all over; corolla tube $c .3 \mathrm{~mm}$ long, lobes $c$. $3 \mathrm{~mm}$ long; inner surface densely minute-hairy, throat with dense exerted erect hairy; filaments $1 \mathrm{~mm}$ long, anthers 1$1.5 \mathrm{~mm}$ long, the whole reflexed and exerted; style 6-8 $\mathrm{mm}$ long, exserted, stigma $c$. $1 \mathrm{~mm}$ long. Fruits globose to obovoid, not bilobed, 4-7 × 3-5 mm; pedicels 6-8 mm long. Pyrene ellipsoid, slightly rugose.

Additional specimens examined: Brunei Darussalam: Tutong: 28 November 1956, J.A.R. Anderson S 4143 (SAR); Telesai, Pasir Putih, $4^{\circ} 45^{\prime} \mathrm{N}, 114^{\circ} 37^{\prime} \mathrm{E}, 8$ April 1995, Salleh Ismail, Ibrahim Abdullah \& Talip Malang BRUN 16595 (SING); 4²5'N, 114 50', 9 May 1952, R.J.Johns 7590 (SING); Pasir Puteh, $10 \mathrm{~km}$, SW of Tutong; north of highway, $4^{\circ} 45^{\prime} \mathrm{N}, 1^{\circ} 4^{\circ} 36^{\prime} \mathrm{E}, 17$ March 1991, M.J.S. Sands \& R.J.Johns 5431 (KEP, SAR); Tutong-Seria Road, at Simpang Tanjong Maya, 12 June 1993, Maung Soe Paing et al. BRUN 15548 (L, SAR, SING); Barakas Forest Reserve, 11 June 1997, I.M. Said et al. BRUN 18477 (SING); Pasir Putih, between Sungai Liang and Tutong, 20 April 1990, M.J.E. Coode et al. 6871 (KEP, SAR, SING). MALAYSIA. Sarawak: Telok Pandan, Bako N.P, 2 June 1963, Paul Chai \& Ilias S 17299 (BO, SING); Bau limestone hills, Tai Tan, 13 October 1977, P.J. Martin S 38677 (KEP, SAN, SAR); Bukit Bisan, Padawan, 38 miles from Kuching, 3 March 1969, Erwin \& Paul S. 27451 (BO, KEP, SAN, SAR, SING); Miri, Lambir National Park, Bukit Lambir, 5 November 1983, leg $S$ 47259 (KEP); Bukit Tai Ton, 12 December 1975, P.F. Stevens et al. 198 (KEP, SAR); Lawas, Bumbung Ramah, Jul 1958, E.F. Brunig S 4410 (SAR); Bidi, Bau, 7 August 1964, J.A.R. Anderson $S 20251$ (SAR); G. Majar, Tebakang, 1st Division, 28 June 1983, Yii \& Othman S 46288 (SAR); 28 November 1955, Brunig $S 6755$ (SAR), Bako National Park, Teluk Pandan path, 4 May 1959, J. Carrick \& I.C. Enoch JC 479 (SAR); Gunong Santubong east, 18 May 1961, H.J. Bujang 13697 (SAR); E.F. Brunig S 2492 (SING); Kuching, Setunggang, Lundu district, 3 August 1996, Lai, Rantai et al. S. 54483 (KEP); Belaga $7^{\text {th }}$ Division, Ulu. Sg. Kayan, Dulit Range, 18 October 1982, Dyg. Awa \& P.C. Yii S. 46872 (SAR). 


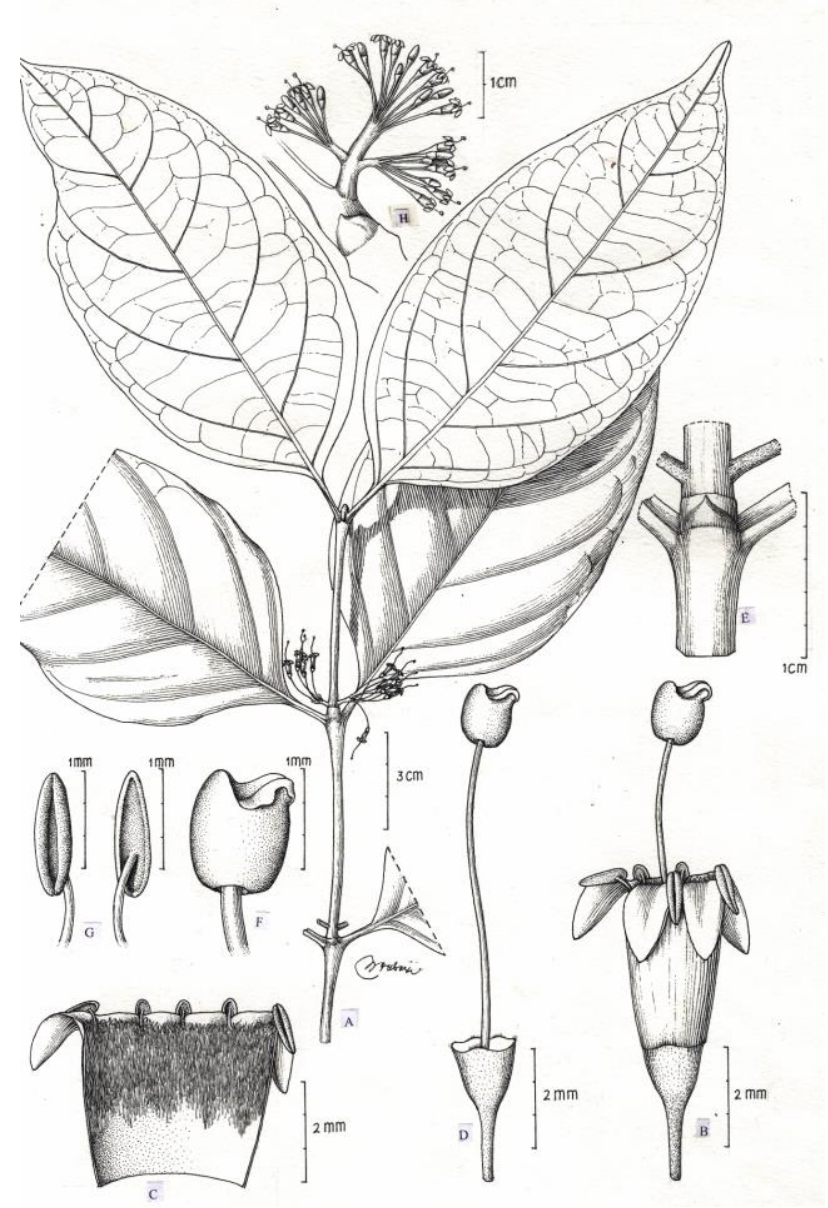

Figure 1. Psydrax sabahensis. A. Branch with open flowers; B. Flower, C. Open corolla, D. Hypanthium, style and stigma, E. Detail showing the quadrangular brach shape, F. Stigma, G. Anther in ventral and dorsal view, H. Inflorescence (SAN 67520). Line drawing by Subari

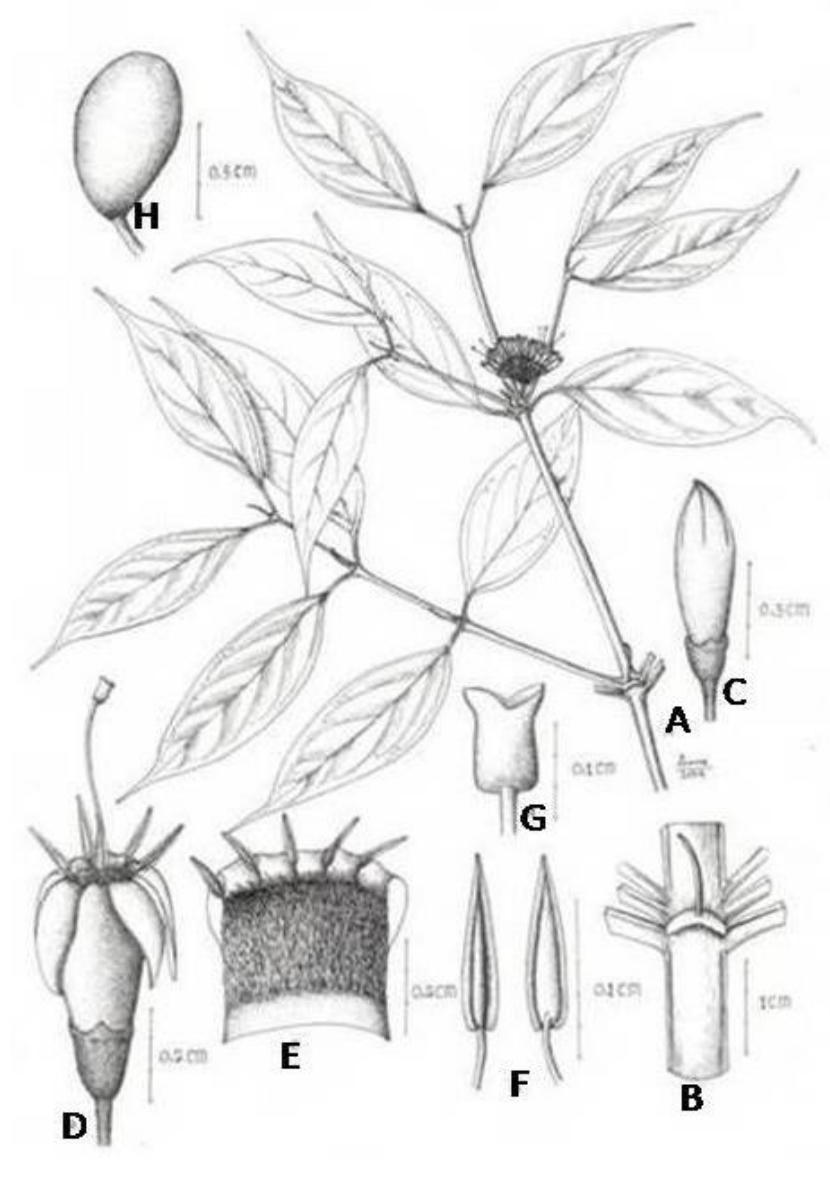

Figure 3. Psydrax wongii. A. Branch with open flowers, B. Stipule, C. Floral bud, D. Flower, E. Open corolla tube, F. Anthers in dorsal and ventral view, G. Stigma, H. Fruit (S 9523 ). Line drawing by Anne Kusumawati.

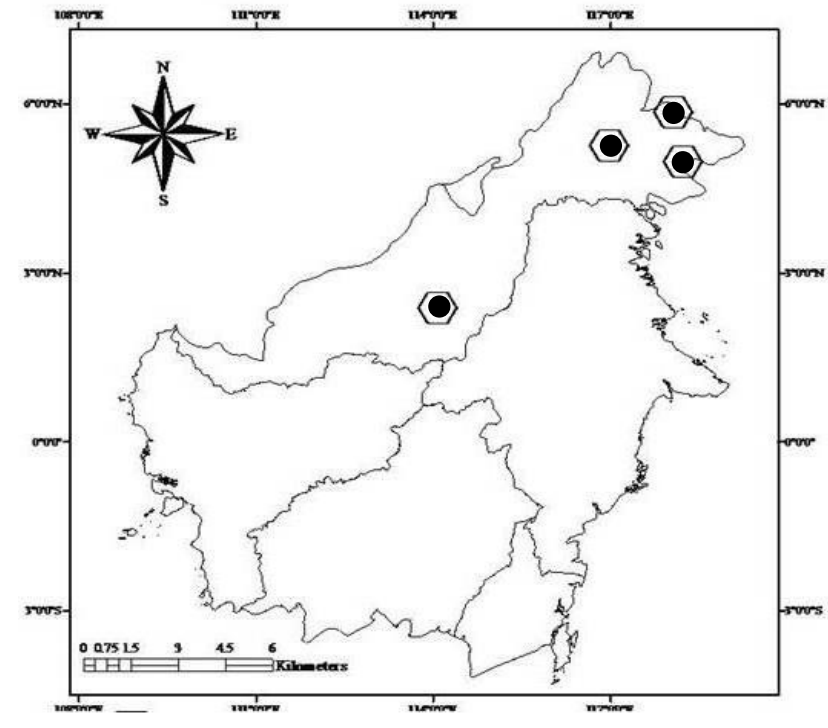

Figure 2. Map of distribution of P. sabahensis in Borneo

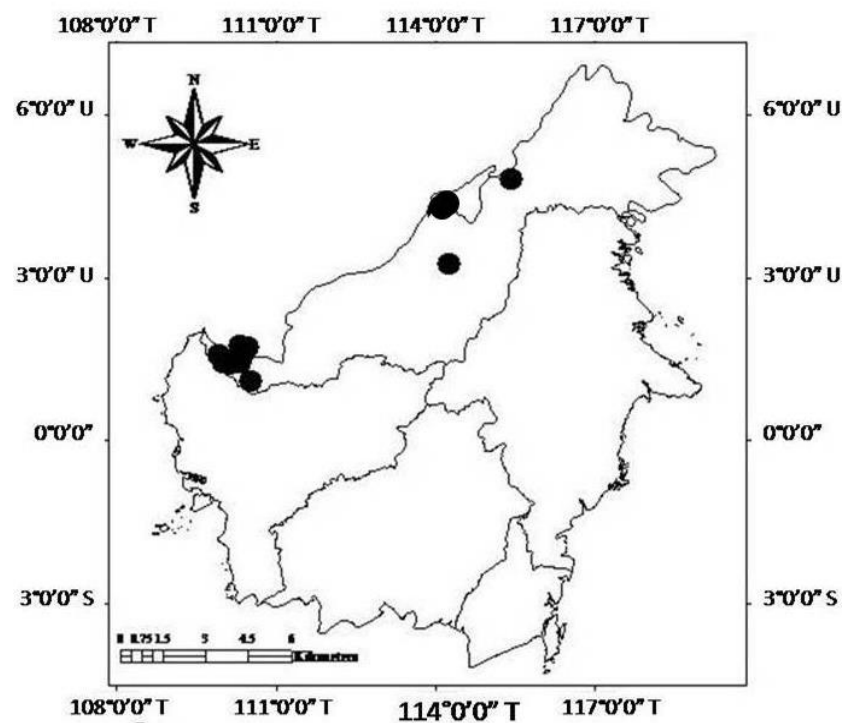

Figure 4. Map of distribution of $P$. wongii in Borneo 
Distribution and habitat: Endemic of Borneo (Brunei Darussalam and Sarawak). Dipterocarp, heat forest to Casuarina to Limestone. (Figure 3).

Etymology: This species name honor Dr. Khoon Meng Wong, due relevant contribution to Rubiaceae study. He has initiated study of the genus Psydrax in Malesia (especially Psydrax in the Malay Peninsula) in 1989.

Local name: kayu-rempak, gusah babi or tulang ular.

Phenology: Flowering from March to October. Fruiting from June to December.

Conservation status: Psydrax wongii had restricted distribution. Although, the distribution includes protected areas. It has to be considered the there has been widespread forest conversion in much of the range. Based on the categories IUCN (2001), that this species indicated Vulnerable A2c.

\section{New record of $\boldsymbol{P}$. maingayi in Borneo}

Previously, Bridson (1985) and Wong (1989) documented P. maingayi (Hook.f) Bridson only for the Malay Peninsula. However, collections of that species from Borneo now are confirmed. Psydrax maingayi has special morphological characters: velvety hairy lower leaf surface, broadly triangular stipules with a pronounced keel or apical lobe, and much-branched lax cymes each 50-60 flowers per inflorescence. In Borneo, it has been documented for East Kalimantan (Indonesia), Bukit Gerugang (Sarawak), Ranau (Sabah) and Tutong (Brunei Darussalam).

Additional specimens examined: Indonesia: Central Kalimantan: Barito Ulu, 12 June 1990, Kade Sidiyasa PBU447 (BO), 18 June 1990, C.E. Risdale PBU73 (BO), East Kalimantan, Kutai, 27 September 1955, F.H. Endert 3637 (BO). MALAYSIA: Sarawak: Bukit Gerugang, 22 March 1998, Enjah A et al., S 77826 (SAR). Sabah, Ranau, 22 September 1971, Leopold, Gary and Dewol SAN 74390 (SAR).

In conclusion, examining specimens from Borneo will be continue. Especially tracing taxa that have been reported from Brunei Darussalam. These six species of Psydrax of Borneo ( $P$. sumatranus, $P$. lucidulus, $P$. approximatus, $P$. maingayi, $P$. sabahensis and $P$. wongii) will be a comparison for the other taxa are later examined.

\section{ACKNOWLEDGEMENTS}

This research is part of a doctoral study of Bornean Psydrax by RM supported by the Ministry of Research, Technology and Higher Education of Indonesia and a Singapore Botanic Gardens fellowship for visiting the Singapore Herbarium. We thank the keepers and curators of the BO, KEP, SAN, SAR and SING herbaria for providing to access to the specimen collections. The study was supervised by Prof. Dr. Mien A. Rifai and Prof. Dr. Tukirin Partomihardjo. We are also grateful to Dr. Ary P. Kiem for suggestion and improvements on this manuscript.

\section{REFERENCES}

Bridson DM. 1985. The reinstatement of Psydrax (Rubiaceae, subfamily Cinchonoideae, tribe Vangueriae) and a revision of the African species. Kew Bulletin 40: 687-725

Coode MJE, Dransfield J, Forman LL, Kirkup, DW, \& Said IM. 1996. A Checklist of the Flowering Plants and Gymnosperms of Brunei Darussalam. Ministry of Industry and Primary Resources, Brunei Darussalam.

IUCN. 2001. IUCN Red List Categories: Version 3.1. IUCN Species Survival Commission, IUCN, Gland, Switzerland and Cambridge, U.K.

Mahyuni R, Chikmawati T, Ariyanti NS, Wong KM. 2018. The Psydrax dicoccos complex (Rubiaceae) in Malesia, with three new species. Floribunda 5 (8): 322-331

Wong KM. 1989. Psydrax Gaertn. (Rubiaceae). In: Ng, FSP, ed. Tree Flora of Malaya. A Manual for Foresters IV. Longman Malaysia Sdn Berhad, Selangor, Malaysia.

Wong KM, Mahyuni R. 2018. Flora of Singapore Precursors, 2. A new species and two new combinations in Psydrax (Rubiaceae: Vanguerieae) for West Malesia. Reinwardtia 17 (1):77-84. 